\title{
Customer Value Perception toward Use of Mobile Banking Applications
}

\section{Reihaneh Bidar}

School of Information Systems

Queensland University of Technology

Brisbane, Australia

Email: r.bidar@qut.edu.au

\section{Abstract}

Mobile banking ( $\mathrm{m}$-banking) is one of the most widely used applications and innovative banking services in the past decade. However, the adoption rate of m-banking in developing countries is low and still has potential for growth. We explored factors and value perceptions of clients toward the use of $m$-banking applications. A conceptual model is presented using the Technology Acceptance Model (TAM) and Uses and Gratification Theory (UGT). The tested variables are Perceived Usefulness, Perceived Ease of Use, Social Integrative, Personal Integrative and Hedonic Benefits. 278 valid survey responses were collected from Iranian and Turkish clients. Multiple regression analysis indicated that Perceived Usefulness and Social Integrative Benefit are the key drivers in both Iran and Turkey, but Hedonic Benefit is only significant in Iran. The results contribute to literature by integrating UGT and TAM and to participate as it enables banks to better design services and to improve customer experience.

Keywords mobile banking, information technology adoption, technology acceptance model, uses and gratification theory. 


\section{Introduction}

Mobile banking (m-banking) refers to branchless banking (Liu et al. 2009), pocket banking (Amin et al. 2007) and mobile finance (Donner and Tellez 2008). Despite the benefits of m-banking (e.g. increased accuracy and speed in processing banking affairs, decreased currency depreciation and reduced cost), the utilisation of m-banking apps is still below market potential. Researchers suggest further investigation of adoption issues in m-banking is needed (Hanafizadeh et al. 2014), especially in developing countries (Mutahar et al. 2018). Riquelme and Rios (2010) anticipated that mobile phones will replace wallets for financial transactions in the near future. However, adoption of technology and services depends on people's knowledge growth and behavioural changes (Constantiou et al. 2007) and developments in technology do not guarantee widespread consumer acceptance (Wang et al. 2008).

This paper identifies two main shortcomings in literature regarding m-banking adoption. Firstly, although many studies have been conducted on m-banking adoption (e.g., Shaikh and Karjaluoto 2015) and factors influencing the use of m-banking (e.g., Alalwan et al. 2016), research focusing on user's value perception is very limited in $\mathrm{m}$-banking context. The importance of identifying user value perception is to identify benefits users expect to achieve from the use of a product/service which will help suppliers to provide support to enhance perception. Secondly, the majority of studies on use of m-banking have applied theory of Technology Acceptance Model (TAM) as the theoretical foundation. However, this paper uses TAM and modifies it to incorporate Uses and Gratification Theory (UGT) to capture user value perception that has been overlooked in the m-banking literature.

This paper focuses on Iran (IR) and Turkey (TR) as developing countries since the rate of m-banking usage among Iranians and Turkish are still growing and are becoming an integrated part of banks' business models (Mohammadi 2015; Onay and Öztaş 2018). In this sense, five variables were selected, and a conceptual model was designed to identify the key factors, as value perceptions, affecting the use of m-banking applications in developing countries. A survey with 26 items was designed and released online. 278 valid data sets were collected and analysed to test the hypotheses in the model. In this paper, I develop a conceptual model integrating TAM and UGT to empirically assess the model, the survey methodology was used. The findings have important implications for research and practice. For research, this study contributes to the literature by integration of UGT from user value perception view and TAM, in m-banking context. The empirical results support three UGT factors (Usefulness, Social Integrative Benefit and Hedonic) that can predict customer use of m-banking applications. For practice, applying social influence and hedonic aspects to the design of app user interface would help to motivate bank clients and provide a richer user experience. Also, it is important for practitioners to improve the functional and operational level of the system to satisfy customer expectations of usefulness and the quality level of services.

\section{LITERATURE REVIEW AND THEORETICAL BACKGROUND}

Researchers have used several theories to explain the adoption of information technologies. The most significant theories exploring the adoption of $\mathrm{m}$-banking include theory of Planned Behaviour (Ajzen 1991), Decomposed Theory of Planned Behaviour (DTPB) (Taylor and Todd 1995), Diffusion of Innovation theory (DOI) (Rogers 1995), Theory of Reasoned Action (TRA) (Fishbein and Ajzen 1975), and TAM (Davis 1989). Wang et al. (2008) recommended a combination of TAM with external variables and network externalities to estimate the adoption of mobile communication innovation among customers. Beiginia et al. (2011) compared TRA, TPB and DTPB to see which model is more appropriate for the adoption of $\mathrm{m}$-banking by consumers. Although there was not a significant difference between TPB and DTPB, DTPB had more influence on the determination of behavioural intention, attitude, and subjective norm and predicted customer's intention to use. A Meta-analysis of TAM showed that while TAM is a useful model for user behaviour on users' intention to use, it needs to be used as the base model (King and He 2006). TAM should be extended using other theories and variables to support contemporary tech-mediated context (Lim 2018).

This paper used TAM as a fundamental model and integrated UGT framework (Katz et al. 1973) as complementary to TAM. Uses and Gratifications is a theory of "why people use a particular kind of media product, and the gratifications they receive from that use" (Lampe et al. 2010). Using UGT helps us to capture the psychological needs which shape people's reason to use a medium to meet specific needs (Katz et al. 1973) and can lead to continuous use (Sangwan 2005). UGT has been used extensively in the social media and communication literature to understand user behaviour. UGT framework includes four attributes including usability, social integrative benefit, personal integrative benefit, and hedonic benefit which manifest the nature of benefits customers expect to gain from their participation in virtual communities (Nambisan and Baron 2009). We follow three main reasons for the integration of TAM 
and UGT: first, this integration helps better understand users' use behaviour and motivations to use through the effect of social, personal, and hedonic factors. Second, while TAM and UGT have been used separately in different contexts, no study covered the integration of these models to establish a stronger grounding to explore customer use behaviour. Finally, studies suggested that TAM requires integration of personal and social, security, and behavioural control factors to include contemporary tech-mediated context (Lim 2018) which is captured in this paper through using UGT.

Many studies investigated drivers influencing m-banking adoption in developed and developing countries. For Iran customers, compatibility, trust, perceived usefulness, credibility, and perceived ease of use were found as acceptable constructs with higher effect on the use of $\mathrm{m}$-banking while the need for interaction, perceived risk and perceived cost had the least influence (Hanafizadeh et al. 2014). Also, in the Iran context, system compatibility has been found to have a major impact on the user's attitude toward m-banking usage while subjective norms and personal innovativeness were mediating factors (Mohammadi 2015). Sheng et al. (2011) reported perceived usefulness, ease of use, compatibility, and risk had an impact on accepting m-banking in China. Yang (2009) presented convenience, security, and competitive basic fee are important to adopt m-banking in Taiwan. Self-efficacy and structural assurance found to be the most significant factors which indirectly influencing intention to use $\mathrm{m}$ banking through usefulness and trust for Korean customers. Also, while a user-friendly interface was found to be essential to develop structural assurance and self-efficacy, factors such as low potential risk, and uncertainty should be reduced ( $\mathrm{Gu}$ et al. 2009). Zhou et al. (2010) found that performance expectancy, task-technology fit, social influence, and facilitating conditions have a significant effect on the adoption. In India however, security, ease of use, and perceived cost, and computer self-efficacy were found to be significant for customers' intention to adopt m-banking (Singh and Srivastava 2018). However, no study investigated value perception related theories such as UGT to identify the main determinants of m-banking use and user value perceptions.

\subsection{M-banking in Iran and Turkey}

Regardless of the broad investigation in the context of m-banking adoption, very few studies have been conducted in the context of Iran (Hanafizadeh et al. 2014; Mohammadi 2015) and Turkey (Altinirmak et al. 2017; Onay and Öztaş 2018). It is important to investigate, as this service is not fully adopted in these countries and many developing countries.

In the context of Iran, Mohammadi (2015) focused on the perception of m-banking usage and Hanafizadeh et al. (2014) explored $m$-banking adoption. They found that the lack of $m$-banking adoption in Iran is because internet banking is still being slowly developed and the growth of $\mathrm{m}$-banking adoption is expected to be even less than internet banking. A survey of e-banking identified Iranian customers preferred to use m-banking compared to other payment gateways such as internet banking and ATM (Aghdam et al. 2017). Nili and Keramati (2012) investigated customer retention in e-banking, showing the correlation between the existing retention programs and success in customer retention. Nahang and Araghi (2013) identified that the virtual bank requirements in the Iranians' banking network depend on external and internal organisational parameters. External organisational factors are uncontrollable and influenced by technical, cultural, educational, economic, and political sectors. This result indicates that a similar factor may affect the adoption of m-banking applications. Mohammadi (2015) believe that there is a lack of knowledge regarding the motivators that influence the adoption of $\mathrm{m}$-banking services in Iran and how to improve the use of m-banking.

In Turkey, as of June 2017, 36 million registered customers logged into m-banking at least, and almost 24 million of them (67\%) used m-banking services actively. This marks a significant increase, as in June 2013 only 2.7 million registered customers actively used m-banking (BanksAssociationTurkey 2017). For Turkish clients, price has been found to be a critical limiting factor for adoption of mobile phone services (Mao et al. 2005) which can lead to a lower intention to use of the new mobile services such as m-banking apps. A study on the adoption of Turkish banks identified that the larger private and local banks are more likely to adopt m-banking in complementary of physical branches (Onay and Öztas 2018). Altinirmak et al. (2017) explored m-banking quality factors among Turkish banks and found Denizbank has the highest performance regarding response time, accuracy, trust and accessibility. From a customer perspective, perceived usefulness, perceived ease of use, security and privacy, compatibility, social influence, facilitating conditions and perceived cost were identified as predictors for the use of mbanking in Turkey (Bidar et al. 2014). 


\subsection{Research Model}

The proposed research model is presented in Figure 1. It examines the various predictors of m-banking use for Iranian and Turkish customers. The model includes Perceived Usefulness (PU), and Perceived Ease of Use (PEOU) that are the basis of TAM. The remaining 3 factors are adopted from UGT (Katz et al. 1973) including Social Integrative Benefit (e.g., Social Influence), Personal Integrative Benefit (e.g., Trust, Compatibility, Individual Mobility, and Perceived Cost) and Hedonic Benefits. Usefulness is also one of the primary constructs in UGT framework. The rationale behind each of the constructs to the context of m-banking is described below.

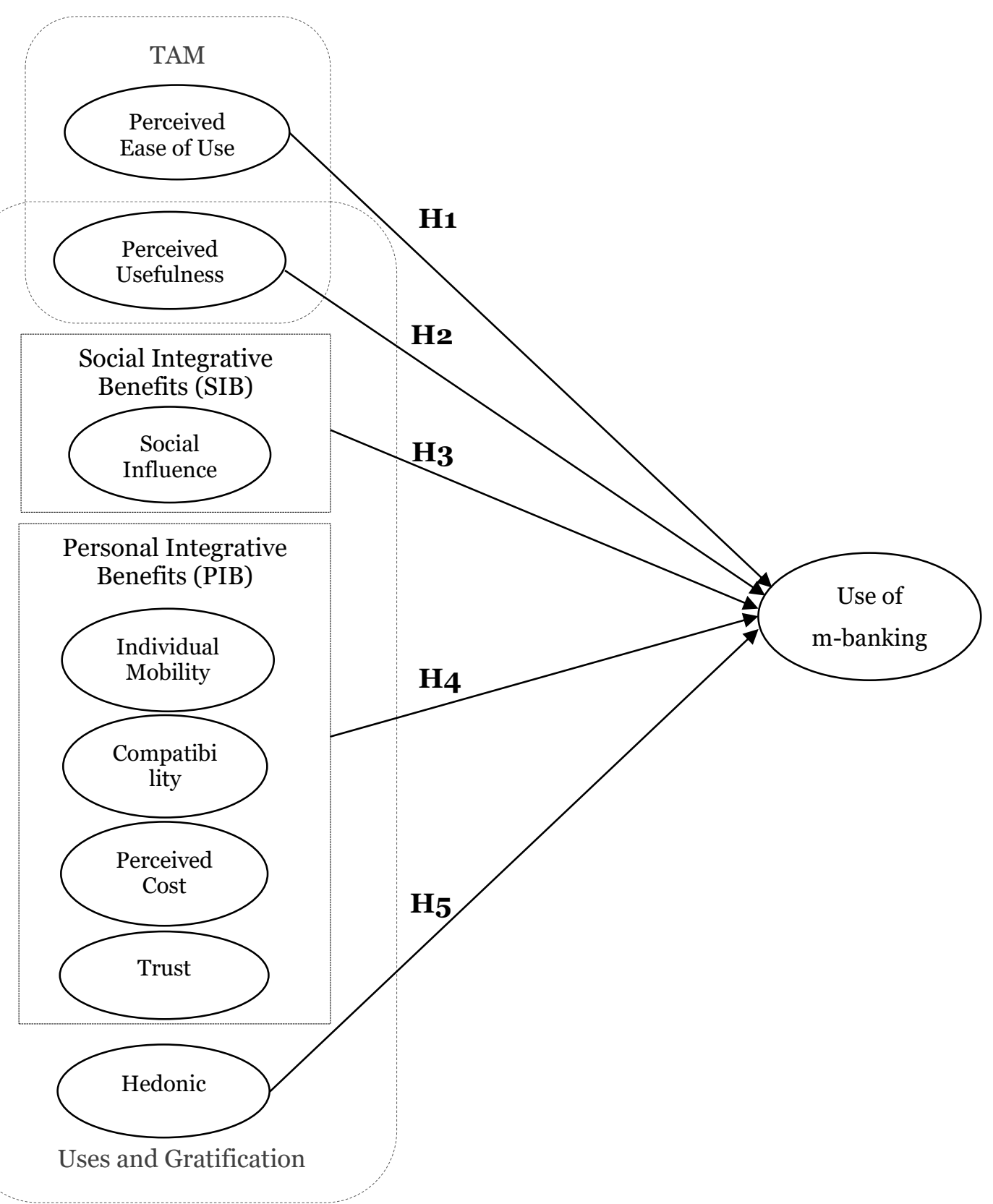

Figure 1: Research model: Use of m-banking in developing countries (Sample of Iran and Turkey).

Perceived ease of use (PEOU) is an individual's belief that the adoption of a system is free of effort (Davis 1989). M-banking systems must be easy to learn and easy to use to prevent interaction problems (Luarn and Lin 2005). PEOU has been found to positively influence $\mathrm{m}$-banking adoption in developing countries such as Iran (Hanafizadeh et al. 2014) and Pakistan (Kazi and Mannan 2016).

H1: Perceived ease of use has a positive effect on use of m-banking apps. 
Perceived Usefulness (PU) is an individual's belief that the adoption of a system would enhance their performance and efficiency (Davis 1989). PU has been discussed in the UGT framework as usability and has been a strong and a positive impact on m-banking usage (Davis 1989; Hanafizadeh et al. 2014; Luarn and Lin 2005). PU was found as the most critical factor influencing $\mathrm{m}$-banking acceptance in both developed and emerging economies (Shaikh and Karjaluoto 2015).

H2: Perceived Usefulness has a positive effect on the use of m-banking.

Social Integrative Benefit (SIB) refers to the benefits a customer gains from the social interactions, including sense of belonging and strengthening consumer's ties with others (Katz et al. 1973). Social influence can be considered as a Social Integrative Benefit. Social influence (SI) and subjective norm were found as social factors influencing $\mathrm{m}$-banking context. Social influence refers to the degree to which people are influenced by others' idea about using the new system (Venkatesh et al. 2003). Subjective norm, as a construct of social influence has been found to be important to the degree in which the social environment perceives mobile payment as desirable (Schierz et al. 2010). Social influence is a factor with a high impact on customers which have more tendencies to use $\mathrm{m}$-commerce by trends, media, and peers (Chong et al. 2012). It was proven that Social influence significantly influences m-banking adoption (Alalwan et al. 2016).

H3: Customer Social Integrative Benefits perceived from m-banking services has a positive effect on use of m-banking apps.

Personal Integrative Benefit (PIB) are related to benefits associated with strengthening the credibility, confidence, and personal needs (KATZ 1974). Prior research has shown that users might act rationally in relation to their self-interest and improvement (Alexander Hars 2002). Some of the personal values investigated in m-banking and online banking adoption are Trust, Individual Mobility, Compatibility, and perceived cost. All these factors are stated as an implication of Personal Integrative Benefit that helps users' improvement.

Trust (T) is customers' beliefs of integrity and desirable idea toward their banks (Luo et al., 2010). Initial and continuance trust are two fundamental elements of trust. Initial trust converts to continuance trust by gaining experiences (Beiginia et al. 2011). Trust has been found as a crucial factor driving customer's m-banking adoption (Zhou 2012) and was found as a key driver for Iranian bank customers (Hanafizadeh et al. 2014).

Compatibility (COM) is the degree to which an innovation is stable with the existing values and beliefs, past experiences, and current needs (Rogers 1995). It is important for firms to focus on compatibility of m-banking with user's daily needs and preferences to attract more users (Sohail and Al-Jabri 2014).

Mobility and pervasiveness of smartphone shift the attention of individuals toward different application services. Individual Mobility (IM) refers to "the degree to which an individual pursues a mobile lifestyle" (Schierz et al. 2010). Few studies explored Individual mobility (e.g., Schierz et al. 2010) and found a positive correlation to intention to use payment services.

Many studies refer to perceived costs as a barrier to accept m-banking (Chong et al. 2012; Dai and Palvi 2009; Hanafizadeh et al. 2014). Customers compare costs and benefits, and if costs exceed the benefits, they refuse to adopt services (Ho Cheong and Park 2005).

H4: Customer Personal Integrative Benefits perceived from m-banking services has a positive effect on use of m-banking apps.

Hedonic Benefit (HED) refers to the customer's entertainment or pleasurable experiences (Katz et al. 1973) and satisfaction gained from using the electronic commerce application (Van der Heijden 2004). Nurture of playfulness in the design of medium lead to customer participation (Kohler et al. 2011). Zhang et al. (2015) also found that the hedonic benefit plays a significant role in intention to participate compared to other UGT benefits. In the context of e-commerce hedonic value is predicted to play a more significant role than usefulness on customer's decision making to adopt the system (Van der Heijden 2004).

H5: Customer Hedonic Benefits perceived from m-banking services has a positive effect on use of mbanking apps.

\section{METHODOLOGY}

A survey questionnaire was designed to investigate major predictors for $\mathrm{m}$-banking acceptance in Iran and Turkey. The scale items adopted mainly from Hanafizadeh et al. (2014), Venkatesh et al. (2003), 
and Lee et al. (2012). The questionnaire included two parts: (1) demographic information; and (2) items related to the variables; In order to ensure validity and trustworthiness of the questions, a small group of $\mathrm{m}$-banking experts and customers checked the questionnairs. Most questions were assessed via a fivepoint Likert scale in a range from strong disagreement to strong agreement. The survey was distributed among university students. A total number of 278 valid responses from participants were gathered.

\section{RESULTS}

Table 1 shows the descriptive statistics of the participants from both countries. 150 Iranian (79 male and 71 female) and 128 Turkish ( 74 male and 54 female) participated in the survey. Most respondents aged between 18 and 40. The results revealed that the primary features performed by mobile financial applications from Iranian viewpoint are checking account, transferring money and paying bills, while Turkish users prefer monitoring credit card, checking account and transferring money.

\begin{tabular}{cccccccc}
\hline \multicolumn{2}{c}{ Category } & \multicolumn{2}{c}{ Total } & \multicolumn{2}{c}{ Iran } & \multicolumn{2}{c}{ Turkey } \\
\hline \multirow{3}{*}{ Gender } & & F & $\%$ & F & $\%$ & F & $\%$ \\
& Male & 153 & 55 & 79 & 52.7 & 74 & 57.8 \\
Age & Female & 125 & 45 & 71 & 47.3 & 54 & 42.2 \\
& $18-25$ & 110 & 39.6 & 41 & 27.3 & 69 & 53.9 \\
& $26-30$ & 90 & 32.4 & 54 & 36 & 36 & 28.1 \\
& $31-40$ & 55 & 19.8 & 37 & 24.7 & 18 & 14.1 \\
Education & $40>$ & 23 & 8.2 & 18 & 12 & 5 & 3.9 \\
& College & 27 & 9.7 & 21 & 14 & 6 & 4.7 \\
& Bachelors & 151 & 54.3 & 59 & 39.3 & 92 & 71.9 \\
& Graduate and above & 100 & 36 & 70 & 46.6 & 30 & 23.4 \\
\hline
\end{tabular}

F: Frequency, \%: Percent

Table 1. Descriptive statistics of the participants.

\subsection{Reliability}

The reliability of the survey for each country was determined separately. Table 2 displays the Cronbach's alpha values of the factors affecting m-banking adoption. The alpha coefficient between 0.6-0.7 represents a lower limit of acceptability, and a reliability coefficient of .70 or higher is considered as high consistency (Hair et al. 2010). The reliability of Hedonic data of Turkish participants and Individual Mobility and Social Influence of Iranians were relatively low, but they are still acceptable. The data for the other factors had high reliability. Overall, $\alpha$ values for the Iranian and Turkish data were .87 and .89 respectively.

\begin{tabular}{|cccc|}
\hline Variable & \# of Items & $\begin{array}{c}\text { Cronbach's alpha } \\
\text { (Iran) }\end{array}$ & $\begin{array}{c}\text { Cronbach's alpha } \\
\text { (Turkey) }\end{array}$ \\
\hline PU & 4 & .87 & .89 \\
PEOU & 3 & .71 & .79 \\
\hline SI & 3 & .65 & .69 \\
\hline TR & 3 & .73 & .85 \\
COM & 3 & .81 & .81 \\
IM & 2 & .60 & .81 \\
PC & 3 & .82 & .85 \\
\hline HED & 2 & .74 & .61 \\
\hline USE & 3 & .82 & .85 \\
\hline
\end{tabular}

Table 2. Reliability of the collected data.

\subsection{Comparison of the Factors}

Independent sample t-test was conducted to compare the variables between the test groups. Table 3 reveals that there is not a significant difference between Trust, Individual Mobility, Perceived Cost and Hedonic in Iran and Turkey. However, significant differences were observed in Perceived Usefulness, Perceived Ease of Use, Compatibility and Social Influence. Perceived Usefulness was significantly 
important for Turkish users ( $\mathrm{t}(252)=-4.63, \mathrm{p}=.000)$. Turkish users have been significantly more attracted by the simplicity of $\mathrm{m}$-banking than Iranians $(\mathrm{t}(237)=-5.70, \mathrm{p}=.000)$. Compatibility was believed more significant in Turkey $(\mathrm{t}(276)=3.10, \mathrm{p}=.002)$. Turkish users were significantly more affected by Social Influence than Iranian users $(t(276)=-2.67, \mathrm{p}=.008)$.

\begin{tabular}{cccccccc}
\hline & Variable & Group & N & Mean & Std. Dev. & $\begin{array}{c}\text { T- } \\
\text { Statistics }\end{array}$ & p-value \\
\hline \multirow{4}{*}{ PU } & IR & 150 & 1.84 & .81 & -4.63 & .000 \\
& & TR & 128 & 2.33 & .94 & & \\
& PEOU & IR & 150 & 1.75 & .72 & -5.70 & .000 \\
& & TR & 128 & 2.33 & .93 & & \\
\hline \multirow{2}{*}{ SIB } & SI & IR & 150 & 2.95 & .85 & -2.67 & .008 \\
& & TR & 128 & 3.21 & .81 & & \\
\hline \multirow{4}{*}{ PIB } & TR & IR & 150 & 2.49 & .89 & .66 & .509 \\
& & TR & 128 & 2.42 & .86 & & \\
& IM & IR & 150 & 1.67 & .82 & -1.51 & .133 \\
& & TR & 128 & 1.83 & .89 & & \\
& PC & IR & 150 & 3.66 & .90 & -.28 & .777 \\
& & TR & 128 & 3.71 & .90 & & \\
& COM & IR & 150 & 2.01 & .85 & -3.10 & .002 \\
& TR & 128 & 2.35 & .95 & & \\
\hline & HED & IR & 150 & 3.44 & 1.09 & -.71 & .478 \\
& TR & 128 & 3.53 & .96 & & \\
\hline
\end{tabular}

Table 3. Mean value comparison of each factor.

\subsection{Correlation among Factors}

Pearson product moment correlation coefficient was calculated to show the correlations between identified variables for each group. This method estimates whether there is a linear relationship between two variables in the population. The correlations among variables in Iran is given as a sample of how we analysed the correlation among factors in Table 4.

All Iranian variables showed positive relationships between the use of m-banking, but the perceived cost had a negative relation. Perceived Usefulness (.610), Perceived Ease of Use (.530), Compatibility (.552), Trust (.558) and Social Influence (.593) had significantly strong relationship individually with the use of m-banking. Positive relationships were observed between PU-PEOU (.583), PU-COM (.574) and SITR (.527). For the Turkish users, significant positive correlations were found between the used of mbanking and Perceived Usefulness (.649), Perceived Ease of Use (.638) and Compatibility (.676). The strongest relationship between variables in Turkey sample belongs to the PU-PEOU (.747) and COMPEOU (.729).

\begin{tabular}{cccccccccc}
\hline & PU & PEOU & COM & TR & SI & FC & PC & HED & USE \\
\hline PU & 1.00 & & & & & & & & \\
PEOU & $.583^{* *}$ & 1.00 & & & & & & & \\
COM & $.574^{* *}$ & $.463^{* *}$ & 1.00 & & & & & \\
TR & $.427^{* *}$ & $.402^{* *}$ & $.480^{* *}$ & 1.00 & & & & \\
SI & $.455^{* *}$ & $.376^{* *}$ & $.405^{* *}$ & $.527^{* *}$ & 1.00 & & & \\
IM & $.321^{* *}$ & $.577^{* *}$ & $.350^{* *}$ & $.342^{* *}$ & $.246^{* *}$ & 1.00 & & \\
PC & $-.175^{*}$ & -.144 & $-.228^{* *}$ & -.153 & .010 & $-.279^{* *}$ & 1.00 & & \\
HED & $.212^{* *}$ & $.289^{* *}$ & $.246^{* *}$ & $.342^{* *}$ & .063 & $.213^{* *}$ & $-.397^{* *}$ & 1.00 & \\
USE & $.610^{* *}$ & $.530^{* *}$ & $.552^{* *}$ & $.558^{* *}$ & $.593^{* *}$ & $.400^{* *}$ & $-.203^{*}$ & $.368^{* *}$ & 1.00 \\
\hline
\end{tabular}

Table 4. Correlation matrix for Iran (Note: $\mathrm{N}=150$ ).

\subsection{Tests of Hypotheses}

Multiple regression analysis was conducted to test the five hypotheses. For Iran, three hypotheses of H1 (Perceived Usefulness), $\mathrm{H}_{3}$ (Social Integrative Benefits) and $\mathrm{H}_{5}$ (Hedonic) were supported to have a 
positive impact on the use of $\mathrm{m}$-banking at $\alpha=.003$. In Turkey, only $\mathrm{H}_{1}$ and $\mathrm{H}_{3}$ were supported to have a positive influence on the use of $m$-banking in Turkey at $\alpha=.003$. Table 5 shows the test results of all hypotheses for the proposed research model.

\begin{tabular}{lcc}
\hline \multicolumn{1}{c}{ Hypotheses } & Iranian & Turkish \\
\hline H1: PU-USE & Supported & Supported \\
H2: PEOU-USE & Rejected & Rejected \\
H3: SIB-USE & Supported & Supported \\
H4: PIB-USE & Rejected & Rejected \\
H5: HED-USE & Supported & Rejected \\
\hline
\end{tabular}

Table 5. The result of testing hypotheses.

\section{DISCUSSION}

The findings of this research provide insight into the factors which are influencing people's use of mbanking instead of traditional banking procedures. The factors which have a significant influence on the use of m-banking in Iran were Perceived Usefulness, Social Integrative Benefit and Hedonic Benefit. Similar to Iran sample, influential factors in use of m-banking in Turkey were Perceived Usefulness and Social Integrative Benefit, but not Hedonic Benefit. Multiple regression analysis was conducted to test the five hypotheses. The $\beta$ value represents the standardised coefficient which shows the strength of the effect of the independent variable on the dependent variable.

The first hypothesis was rejected for both countries (Iran: $\beta=.063, p>.05$; Turkey: $\beta=.111, p>.05$ ). Liu et al. (2009) also found out that perceived ease of use has no significant influence on the user acceptance of m-banking. In contrast, in the developing country context, PEOU was found as a significant factor in the previous studies (Hanafizadeh et al. 2014; Kazi and Mannan 2016). However, this paper does not confirm a relation between PEOU and use of m-banking in developing countries. Since computer-based systems have become more common these days and people have acquired more knowledge and experience of using smartphones and new applications, there will be less concern about the complexity of the new systems.

The second hypothesis stated that Perceived Usefulness positively influences the use of m-banking apps in both Iran and Turkey. This claim is supported significantly by our findings (Iran: $\beta=.242, \mathrm{p}<.01$; Turkey: $\beta=.279, p<.01$ ). This further explains that the more customers realise $m$-banking services to be useful, the more they will be absorbed into the use of m-banking apps. Dai and Palvi (2009) and Amin et al. (2007) also found that Perceived Usefulness of m-banking influences the adoption of novice technologies.

$\mathrm{H}_{3}$ was accepted and Social Integrative Benefit was found to have a positive effect on m-banking usage (Iran: $\beta=.320, \mathrm{p}<.01$; Turkey: $\beta=.170, \mathrm{p}<.05$ ). Similar to the findings of Zhou et al. (2010) in which social influence is a significant determinant of $\mathrm{m}$-banking and online banking acceptance. Son et al. (2012) believe the positive effect of mobile computing devices among social circle increases the idea to which the system is useful. Therefore, the high impact of social factors reveals that friends, social networks, gamification methods influence customers and these interactions can form their opinions and decisions.

H4 which supposed a positive impact of Personal Integrative Benefits on use of m-banking was not supported. The results demonstrate that the essential requirements for m-banking usage such as mobility were provided in these two countries. Regarding to perceived cost, cellular phone users have more tendency to use m-banking services than any others (Hanafizadeh et al. 2014). In contrast, perceived financial cost was found as a significant barrier for users of mobile banking (Luarn and Lin 2005). Min et al. (2008) identified trust, privacy, convenience, and cost as the original determinants in affecting the behavioural intuition of Chinese clients. Although trust in using a new system is always a concern for users, we found that Iranian and Turkish customers believe their banks as a reliable organisation. Adequate knowledge and familiarity of respondents with mobile applications and working up-to-date with banks reduce their disbelief on using m-banking. Hanafizadeh et al. (2014) also identified trust as the most significant antecedents explaining the adoption of m-banking. Compatibility is believed very important for easy use of various systems and products and increasing popularity of mbanking (Hanafizadeh et al. 2014; Lin 2011). However, these personal factors failed to have a significant impact on the use of m-banking in the context of this paper. 
Hedonic Benefit ( $\mathrm{H}_{5}$ ) was observed to have a significant positive impact on the use of $\mathrm{m}$-banking in Iran. However, it was not a critical factor in Turkey (Iran: $\beta=.189, p<.01$; Turkey: $\beta=.053, p>.05$ ). Users with higher playfulness perception have greater use of $m$-banking applications and enjoyment from their usage and usefulness of $\mathrm{m}$-banking. Therefore, the use of $\mathrm{m}$-banking applications is higher in Iran when users believe that the service application provides greater hedonic experience.

This paper has three main contributions. From the conceptual viewpoint, we present a model developed from two theories related to the consumer use behaviour in adopting new IS system. The proposed model is an extension of Dai and Palvi (2009) TAM with UGT to m-banking context. The extended model provides a more holistic view of the drivers of user acceptance of m-banking services compared to previous studies. Integration of UGT framework with TAM provides a stronger grounding to explore the use of a new system and helps to reduce the constraint of TAM by supporting the social and hedonic aspects. Specifically, testing the model through different stability tests and using a large sample provides confidence in the findings. Second, the findings of this paper show some significant contributions to the management of mobile services by financial institutions. In particular, an understanding of m-banking process could be quite useful for determining those strategies and actions that better fit consumers' preferences and demands. For example, in both Iran and Turkey banks should focus more on improving functional and operational implementation of the m-banking apps. Also, improving user experience through creating a more gamified design features helps practitioners to create a positive social influence in both countries and satisfy the hedonic benefits for Iranian customers. Finally, this paper provides an insight to the practitioners in filling the lack of knowledge on factors influencing $\mathrm{m}$-banking applications in Turkey and Iran, as both are developing countries. There is still a new market opportunity in both countries.

\section{CONCLUSION}

This paper focused on consumer behaviour on the use of m-banking services. Previous studies on mbanking have used TRA, TPB, and TAM to measure consumer behavioural intention. This paper established an accurate measurement to predict and explain consumer willingness and use of $m$-banking applications and services through integrating TAM and UGT. We extended TAM using UGT framework to find out people's value perception toward the use of m-banking. We applied multiple regression analysis to determine which variables maintain more persuasive power on use of $\mathrm{m}$-banking. Perceived Usefulness, Social Integrative Benefit and Hedonic Benefit in Iran and Perceived Usefulness and Social Integrative Benefit in Turkey were found as the most important values and drivers in explaining user's use of m-banking. A system that is aligned with the customers' daily needs would have a more positive effect on the m-banking usage. On the other hand, banks in Iran need to employ strategies to enhance Hedonic and playfulness experience through the design of m-banking apps for increasing the number of consumers. Additionally, positive feedback from peers, friends and the impact of advertisements would improve the customers' tendency toward usage of m-banking in both countries.

\section{REFERENCES}

Aghdam, A. R., Xu, S., Kaveie, A., Fahimi, S. A., Khani, E. G., and Kamalpour, M. 2017. "Performance Assessment of Payment Gateways in Banking Services in Tehran, Iran," International Journal on Computer Science and Engineering (9:8), pp. 496-505.

Ajzen, I. 1991. "The Theory of Planned Behavior," Organizational Behavior and Human Decision Processes (50:2), pp. 179-211.

Alalwan, A. A., Dwivedi, Y. K., Rana, N. P., and Williams, M. D. 2016. "Consumer Adoption of Mobile Banking in Jordan: Examining the Role of Usefulness, Ease of Use, Perceived Risk and SelfEfficacy," Journal of Enterprise Information Management (29:1), pp. 118-139.

Alexander Hars, S. O. 2002. "Working for Free? Motivations for Participating in Open-Source Projects," International Journal of Electronic Commerce (6:3), pp. 25-39.

Altinirmak, S., Okoth, B., Ergun, M., and Karamasa, C. 2017. "Analyzing Mobile Banking Quality Factors under Neutrosophic Set Perspective: A Case Study of Turkey," Journal of Economics Finance and Accounting (4:4), pp. 354-367.

Amin, H., Baba, R., and Muhammad, M. Z. 2007. "An Analysis of Mobile Banking Acceptance by Malaysian Customers," Sunway academic journal (4), pp. 1-12.

BanksAssociationTurkey. 2017. "Digital, Internet and Mobile Banking Statistics ").

Beiginia, A. R., Besheli, A. S., Soluklu, M. E., and Ahmadi, M. 2011. "Assessing the Mobile Banking Adoption Based on the Decomposed Theory of Planned Behaviour," European Journal of Economics, Finance and Administrative Sciences (28:1), pp. 7-15. 
Bidar, R., Fard, M. B., Salman, Y. B., Tunga, M. A., and Cheng, H. 2014. "Factors Affecting the Adoption of Mobile Banking: Sample of Turkey," 16th International Conference on Advanced Communication Technology, pp. 1278-1282.

Chong, A. Y.-L., Chan, F. T., and Ooi, K.-B. 2012. "Predicting Consumer Decisions to Adopt Mobile Commerce: Cross Country Empirical Examination between China and Malaysia," Decision Support Systems (53:1), pp. 34-43.

Constantiou, I. D., Damsgaard, J., and Knutsen, L. 2007. "The Four Incremental Steps toward Advanced Mobile Service Adoption," Communications of the ACM (50:6), pp. 51-55.

Dai, H., and Palvi, P. C. 2009. "Mobile Commerce Adoption in China and the United States: A CrossCultural Study," ACM SIGMIS Database: the DATABASE for Advances in Information Systems (40:4), pp. 43-61.

Davis, F. D. 1989. "Perceived Usefulness, Perceived Ease of Use, and User Acceptance of Information Technology," MIS quarterly), pp. 319-340.

Donner, J., and Tellez, C. A. 2008. "Mobile Banking and Economic Development: Linking Adoption, Impact, and Use," Asian journal of communication (18:4), pp. 318-332.

Fishbein, M., and Ajzen, I. 1975. Belief, Attitude, Intention and Behavior: An Introduction to Theory and Research.

Gu, J.-C., Lee, S.-C., and Suh, Y.-H. 2009. "Determinants of Behavioral Intention to Mobile Banking," Expert Systems with Applications (36:9), pp. 11605-11616.

Hair, J. F., Black, W. C., Babin, B. J., and Anderson, R. E. 2010. Multivariate Data Analysis, (7th ed. ed.). Upper Saddle River, NJ: Prentice Hall.

Hanafizadeh, P., Behboudi, M., Koshksaray, A. A., and Tabar, M. J. S. 2014. "Mobile-Banking Adoption by Iranian Bank Clients," Telematics and Informatics (31:1), pp. 62-78.

Ho Cheong, J., and Park, M.-C. 2005. "Mobile Internet Acceptance in Korea," Internet research (15:2), pp. 125-140.

Katz, E., Blumler, J. G., and Gurevitch, M. 1973. "Uses and Gratifications Research," The public opinion quarterly (37:4), pp. 509-523.

Kazi, A. K., and Mannan, M. A. 2016. "Factors Affecting Adoption of Mobile Banking in Pakistan: Empirical Evidence," International Journal of Research in Business and Social Science (21474478) (2:3), pp. 54-61.

Keramati, A., and Nili, A. 2011. "A Proposal Framework for Investigating the Impact of Customer Relationship Management on Customer Retention in E-Commerce," human resources (6:9), p. 26.

King, W. R., and He, J. 2006. "A Meta-Analysis of the Technology Acceptance Model," Information \& management (43:6), pp. 740-755.

Kohler, T., Fueller, J., Matzler, K., and Stieger, D. 2011. "Co-Creation in Virtual Worlds: The Design of the User Experience," MIS Quarterly (35:3), p. 773.

Lampe, C., Wash, R., Velasquez, A., and Ozkaya, E. 2010. "Motivations to Participate in Online Communities," Proceedings of the SIGCHI conference on Human factors in computing systems: ACM, pp. 1927-1936.

Lee, J., Lee, M., and Choi, I. H. 2012. "Social Network Games Uncovered: Motivations and Their Attitudinal and Behavioral Outcomes," Cyberpsychology, Behavior, and Social Networking (15:12), pp. 643-648.

Lim, W. M. 2018. "Dialectic Antidotes to Critics of the Technology Acceptance Model: Conceptual, Methodological, and Replication Treatments for Behavioural Modelling in TechnologyMediated Environments," Australasian Journal of Information Systems (22).

Lin, H.-F. 2011. "An Empirical Investigation of Mobile Banking Adoption: The Effect of Innovation Attributes and Knowledge-Based Trust," International journal of information management (31:3), pp. 252-26o.

Liu, Z., Min, Q., and Ji, S. 2009. "An Empirical Study on Mobile Banking Adoption: The Role of Trust," Electronic Commerce and Security, 2009. ISECS'09. Second International Symposium on: IEEE, pp. 7-13.

Luarn, P., and Lin, H.-H. 2005. "Toward an Understanding of the Behavioral Intention to Use Mobile Banking," Computers in human behavior (21:6), pp. 873-891.

Mao, E., Srite, M., Bennett Thatcher, J., and Yaprak, O. 2005. "A Research Model for Mobile Phone Service Behaviors: Empirical Validation in the Us and Turkey," Journal of Global Information Technology Management (8:4), pp. 7-28.

Min, Q., Ji, S., and Qu, G. 2008. "Mobile Commerce User Acceptance Study in China: A Revised Utaut Model," Tsinghua Science and Technology (13:3), pp. 257-264.

Mohammadi, H. 2015. "A Study of Mobile Banking Loyalty in Iran," Computers in Human Behavior (44), pp. 35-47. 
Mutahar, A. M., Daud, N. M., Thurasamy, R., Isaac, O., and Abdulsalam, R. 2018. "The Mediating of Perceived Usefulness and Perceived Ease of Use: The Case of Mobile Banking in Yemen," International Journal of Technology Diffusion (IJTD) (9:2), pp. 21-40.

Nahang, F., and Araghi, K. 2013. "Internal Factors Affecting the Profitability of City Banks," International Research Journal of Applied and Basic Sciences (5:12), pp. 1491-1500.

Nambisan, S., and Baron, R. A. 2009. "Virtual Customer Environments: Testing a Model of Voluntary Participation in Value Co-Creation Activities," Journal of product innovation management (26:4), pp. 388-406.

Nili, A., and Keramati, A. 2012. "Customer Retention Programs of Crm and Customer Retention in EBanking," International Journal of E-Entrepreneurship and Innovation (IJEEI) (3:1), pp. 1832.

Onay, C., and Öztaş, Y. E. 2018. "Why Banks Adopt Mobile Banking? The Case of Turkey," International Journal of Electronic Finance (9:2), pp. 95-120.

Riquelme, H. E., and Rios, R. E. 2010. "The Moderating Effect of Gender in the Adoption of Mobile Banking," International Journal of bank marketing (28:5), pp. 328-341.

Rogers, E. M. 1995. "Lessons for Guidelines from the Diffusion of Innovations," Joint Commission Journal on Quality and Patient Safety (21:7), pp. 324-328.

Sangwan, S. 2005. "Virtual Community Success: A Uses and Gratifications Perspective," System Sciences, 2005. HICSS'05. Proceedings of the 38th Annual Hawaii International Conference on: Ieee, pp. 193c-193c.

Schierz, P. G., Schilke, O., and Wirtz, B. W. 2010. " Understanding Consumer Acceptance of Mobile Payment Services: An Empirical Analysis. ," Electronic commerce research and applications, (9:3), pp. 209-216.

Shaikh, A. A., and Karjaluoto, H. 2015. "Mobile Banking Adoption: A Literature Review," Telematics and Informatics (32:1), pp. 129-142.

Sheng, M., Wang, L., and Yu, Y. 2011. "An Empirical Model of Individual Mobile Banking Acceptance in China," Computational and Information Sciences (ICCIS), 2011 International Conference on: IEEE, pp. 434-437.

Singh, S., and Srivastava, R. 2018. "Predicting the Intention to Use Mobile Banking in India," International Journal of Bank Marketing (36:2), pp. 357-378.

Sohail, M. S., and Al-Jabri, I. M. 2014. "Attitudes Towards Mobile Banking: Are There Any Differences between Users and Non-Users?," Behaviour \& Information Technology (33:4), pp. 335-344.

Son, H., Park, Y., Kim, C., and Chou, J.-S. 2012. "Toward an Understanding of Construction Professionals' Acceptance of Mobile Computing Devices in South Korea: An Extension of the Technology Acceptance Model," Automation in construction (28), pp. 82-90.

Taylor, S., and Todd, P. A. 1995. "Understanding Information Technology Usage: A Test of Competing Models," Information systems research (6:2), pp. 144-176.

Van der Heijden, H. 2004. "User Acceptance of Hedonic Information Systems," MIS quarterly), pp. 695-704.

Venkatesh, V., Morris, M. G., Davis, G. B., and Davis, F. D. 2003. "User Acceptance of Information Technology: Toward a Unified View," MIS quarterly), pp. 425-478.

Wang, C. C., Lo, S. K., and Fang, W. 2008. "Extending the Technology Acceptance Model to Mobile Telecommunication Innovation: The Existence of Network Externalities," Journal of Consumer Behaviour: An International Research Review (7:2), pp. 101-110.

Yang, A. S. 2009. "Exploring Adoption Difficulties in Mobile Banking Services," Canadian Journal of Administrative Sciences/Revue Canadienne des Sciences de l'Administration (26:2), pp. 136149.

Zhang, H., Lu, Y., Wang, B., and Wu, S. 2015. "The Impacts of Technological Environments and CoCreation Experiences on Customer Participation," Information \& Management (52:4), pp. 468482.

Zhou, T. 2012. "Understanding Users' Initial Trust in Mobile Banking: An Elaboration Likelihood Perspective," Computers in Human Behavior (28:4), pp. 1518-1525.

Zhou, T., Lu, Y., and Wang, B. 2010. "Integrating Ttf and Utaut to Explain Mobile Banking User Adoption," Computers in human behavior (26:4), pp. 760-767.

Copyright: (C) 2018 Reihaneh Bidar. This is an open-access article distributed under the terms of the Creative Commons Attribution-NonCommercial 3.0 Australia License, which permits non-commercial use, distribution, and reproduction in any medium, provided the original author and ACIS are credited. 